\title{
Effect of high and low energy based concentrate diet supplementation on nutrient intake and body weight changes of buffalo bull calves at Subornochar Upozila of Noakhali district in Bangladesh
}

\author{
MA Siddiki ${ }^{1}$, MR Amin ${ }^{1 *}$, AKMA Kabir ${ }^{1}$, MO Faruque ${ }^{2}$ and ZH Khandaker ${ }^{3}$ \\ ${ }^{1}$ Department of Animal Science, Bangladesh Agricultural University, Mymensingh 2202, Bangladesh; \\ ${ }^{2}$ Department of Animal Breeding and Genetics, Bangladesh Agricultural University, Mymensingh 2202, \\ Bangladesh; ${ }^{3}$ Department of Animal Nutrition, Bangladesh Agricultural University, Mymensingh 2202, \\ Bangladesh
}

\begin{abstract}
This study was designed to investigate the effects of supplementation of high and low energy based concentrate diets (13.77 Vs $12.14 \mathrm{MJ} / \mathrm{kg}$ DM metabolizable energy) on the nutrient intake and body weight changes of indigenous growing buffalo bull calves in Bangladesh. The crude protein contents of both the supplemented diets were similar (about $12.50 \%$ on DM basis). In this study, a total of fifteen indigenous growing buffalo bull calves (av. Live weight $85.10 \pm 0.874 \mathrm{~kg}$ ) were selected from different villages. It was found that the total dry matter intake was the highest $\left(28.22 \pm 0.015 \mathrm{~g} / \mathrm{kg} \mathrm{W}^{0.75} / \mathrm{d}\right)$ in group supplemented with high energy concentrate diet along with farmer's practices $\left(D_{1}\right)$, thereafter, in group supplemented with low energy concentrate diet along with farmer's practices $\left(D_{2}\right)(27.79 \pm 0.015$ $\left.\mathrm{g} / \mathrm{kg} \mathrm{W}^{0.75} / \mathrm{d}\right)$ and the lowest $\left(26.39 \pm 0.016 \mathrm{~g} / \mathrm{kg} \mathrm{W}^{0.75} / \mathrm{d}\right)$ in control group $\left(D_{0}\right)$ in which the animals were fed only farmers practices diet. Similarly, the crude protein intake was the highest in $D_{1}$ group $\left(2.86 \pm 0.029 \mathrm{~g} / \mathrm{kg} \mathrm{W}^{0.75} / \mathrm{d}\right)$, followed by $D_{2}$ group $\left(2.83 \pm 0.010 \mathrm{~g} / \mathrm{kg} \mathrm{W}^{0.75} / \mathrm{d}\right)$ and the lowest in farmer's practices diet, $D_{0}\left(2.08^{\mathrm{b}} \pm 0.021 \mathrm{~g} / \mathrm{kg} \mathrm{W}^{0.75} / \mathrm{d}\right)$. However, the final body weight of buffalo bull calves was higher in both groups supplemented with concentrate diets $\left(D_{1}\right.$ and $\left.D_{2}\right)$ compared with control $\left(D_{0}\right)$ and differed significantly $(p<0.01)$ while there were no significant differences $(p>0.05)$ found between $D_{1}$ and $D_{2}$ where high energy concentrate supplementation group buffalo bull claves, $D_{1}$ tended to be higher than low energy concentrate supplementation group buffalo bull claves, $D_{2}$. The highest final $(254.6 \mathrm{~kg})$ body weight was recorded in high energy concentrate supplemented diets and the lowest $(144.0 \mathrm{~kg})$ was found in control. Additionally, the average final body weight was increased by $153.40 \mathrm{~kg}$ $(151.58 \%), 150.40 \mathrm{~kg}(152.22 \%)$ and $45.60 \mathrm{~kg}(46.34 \%)$ in $D_{1}, D_{2}$ and $D_{0}$ group buffalo bull calves, respectively. On the other hand, the average final body weight of $D_{1}$ and $D_{2}$ was increased by $110.60 \mathrm{~kg}$ $(76.80 \%)$ and $105.20 \mathrm{~kg}(73.05 \%)$, respectively, compared with $D_{0}$. In addition, the highest (6.46) feed conversion efficiency (FCE) was recorded in $D_{1}$ followed by $D_{2}(6.64)$ and the lowest (12.17) was found in $D_{0}$. The trends of cost benefit ratio was the same like other considering factors, the highest $(1: 3.60)$ found in $D_{1}$ followed by $D_{2}(1: 3.51)$ and the lowest $(1: 1.97)$ in $D_{0}$. Finally, considering all the parameters, it was clearly indicated that supplementation of concentrate diet along with farmers practice is essential for fast growing, higher body weight gain and more benefits by rearing buffalo bull calves at Subornochar Upozila of Noakhali district in Bangladesh.
\end{abstract}

Keywords: buffalo, nutrient intake, body weight gain, feed conversion ratio, cost benefit, buffalo farmer

\section{Introduction}

The economy of Bangladesh is depending on agriculture, and livestock is an essential component of the rural as well as national economy which is the predominant source of income generation. The contribution of livestock sub-sector to GDP was $1.60,1.54,1.47$ and 1.43 percent in FY 2016-2017, 2017-2018, 2018-2019 and 2019-2020 respectively. The growth of this sub-sector was about $2.9 \%$ of national GDP is covered by the livestock sector, and its annual rate of growth is $5.5 \%$ (Banglapedia, 2021) and $13 \%$ of the total foreign exchange earnings from this sector (BBS, 2011). Seventy percent (20\% people are directly engaged and $50 \%$ are partly associated) people of the country depend on livestock to some extent for their income, which 
clearly indicate that the poverty reduction potential of this sub-sectors is high (Begum et al., 2011; DLS, 2020; Banglapedia, 2021). Bangladesh is one of the most concentrated livestock populated country in the world, 145 large ruminant's presence per sq $\mathrm{km}$ compared with 94 for India, 30 for Ethiopia and 20 for Brazil (Anonymous, 2007; NARS, 2010). In Bangladesh, livestock contributing through the production of 106.80 lakh metric ton and 76.74 lakh metric ton milk and meat, respectively in fiscle year 20192020 (DLS, 2020). Buffalo meat is popular in most buffalo producing countries. The world meat production is 311.8 MMT (FAOSTAT, 2014), and buffaloes contribute about 3 MMT. India has about 98 million buffaloes, which is $57 \%$ of total population in the world and about $43 \%$ of the world buffalo meat production and produces 1.48 MMT amounting $24.54 \%$ of the total meat produced in the country (FAO, 2008). Buffalo meat constitutes with high protein (above 11\%) and low cholesterol (Kandeepan et al., 2009). The buffalo meat is the healthiest meat among red meats known for human consumption because it is low in calories. The meat from young buffalo and cattle has clearly shown that buffalo meat is indeed as good as cattle meat (Heinz, 2001) and buffalo meat is tenderer and less in cholesterol $(55 \%)$ than beef (Neath et al., 2007). Feeding high levels of protein may be effective in promoting rapid live weight gains, especially growing buffalo (Basra et al., 2003b). It has been indicated that the optimum fattening performance of 15 months old Nili-Ravi buffalo male calves may be obtained by providing $10.42 \mathrm{MJ} / \mathrm{kg}$ of dietary metabolizable energy and about $10.22 \%$ of crude protein (Mahmoudzadeh et al., 2007) and $12 \% \mathrm{CP}$ for 11 to 12 months old male buffalo calves (Tipu et al., 2009). Laxmi et al., (2014) found that supplemented group attain higher weight gain ( 0.53 to $1.0 \mathrm{~kg} /$ day) compared to control ( 0.43 to $0.70 \mathrm{~kg} /$ day). Helal et al., (2011) reported that calves fed $100 \%$ concentrate gained more than the other two groups $(957,941$ and $1017 \mathrm{~g} /$ day). In Bangladesh, the role of buffaloes is not much emphasized and the species did not receive due attention by the policy makers and the researchers. Very little work has been done so far on the effect of supplementation of protein and energy based diet on body weight gain of growing buffalo bull calves. Therefore, considering the above discussion, the present study was undertaken to know the effects of supplementation of protein and energy rich diets on growth performance of buffalo bull calves in Subornochar Upozila at Noakhali district in Bangladesh which is known as delta land located on the tidal floodplain of the Meghna River delta.

\section{Materials and Methods}

\section{Selection of study area}

The study was conducted at Subornochar Upozila of Noakhali district in Bangladesh during the period of 240 days from September 2013 to Apri 2014. Subarnachar Upazila is an island, low-lying coastal areas of Bangladesh and highly vulnerable to natural disasters, located in between $22^{\circ} 28$ and $22^{\circ} 44^{\prime}$ north latitudes and in between $90^{\circ} 59$ and $91^{\circ} 20^{\prime}$ east longitudes. The livelihoods mainly depend on agriculture more specifically livestock and fishing.

\section{Housing and management practices}

The buffaloes were reared by the owners under conventional housing and improved management practices. A good sanitary condition and almost uniform management practice were maintained throughout the experimental period. All the buffaloes were vaccinated with FMD, anthrax, black quarter and HS for prevention of contagious diseases and dewormed for internal parasites using anthelmintic drugs and allowed two weeks to adapt the experimental conditions prior to the commencement of the study.

Table 1: Experimental layout and dietary treatments for growing buffalo

\begin{tabular}{|c|c|c|c|}
\hline \multirow{2}{*}{ Parameters } & \multicolumn{3}{|c|}{ Treatments } \\
\hline & $D_{0}$ & $\mathbf{D}_{1}$ & $\mathbf{D}_{2}$ \\
\hline $\begin{array}{l}\text { Number of } \\
\text { growing buffalo }\end{array}$ & 5 & 5 & 5 \\
\hline $\begin{array}{l}\text { Average initial } \\
\text { live weight (kg) } \\
\text { (Av. } \pm \text { SEM) }\end{array}$ & $\begin{array}{c}83.30 \pm \\
3.43\end{array}$ & $\begin{array}{c}86.30 \pm \\
3.32\end{array}$ & $\begin{array}{c}85.70 \pm \\
3.00\end{array}$ \\
\hline $\begin{array}{l}\text { Supplementation } \\
\text { of concentrate } \\
\text { diet }(\mathrm{kg} / \text { day })\end{array}$ & $\begin{array}{l}\text { No } \\
\text { supplemen } \\
\text { tation }\end{array}$ & $\begin{array}{c}1.52 \pm \\
0.04\end{array}$ & $\begin{array}{c}1.49 \pm \\
0.36\end{array}$ \\
\hline
\end{tabular}

Do, Farmer's diets (FD) only without the supplementation of concentrate; $D_{1}, F D+$ supplemented with high energy concentrate diet; $D_{2}$, $F D+$ supplemented with low energy concentrate diet

\section{Experimental layout and dietary treatments}

The experimental layout and dietary treatments are shown in Table 1 . The experiment was conducted for a period of 240 days started with two weeks of adjustment period from September 2013 to April 2014. After adjustment period, the experimental buffalo bull calves were randomly allocated into three (3) treatment groups having five buffaloes in each group. 


\section{Supplementation of concentrate diet to growing bull calf}

Table 2: Ingredient and nutrient composition of supplemented concentrate diet

\begin{tabular}{|c|c|c|c|}
\hline Ingredients & $\begin{array}{c}D_{0} \\
\text { (Control) }\end{array}$ & $D_{1}$ & $\mathbf{D}_{\mathbf{2}}$ \\
\hline $\begin{array}{l}\text { Crushed } \\
\text { Maize }(\mathrm{g} / \mathrm{kg})\end{array}$ & 0 & 400 & 0 \\
\hline $\begin{array}{l}\text { Rice polish } \\
(\mathrm{g} / \mathrm{kg})\end{array}$ & 0 & 200 & 325 \\
\hline $\begin{array}{l}\text { Broken rice } \\
(\mathrm{g} / \mathrm{kg})\end{array}$ & 0 & 250 & 250 \\
\hline $\begin{array}{l}\text { Wheat bran } \\
(\mathrm{g} / \mathrm{kg})\end{array}$ & 0 & 120 & 400 \\
\hline Urea (g/kg) & 0 & 5 & 0 \\
\hline DCP $(\mathrm{g} / \mathrm{kg})$ & 0 & 15 & 15 \\
\hline $\begin{array}{l}\text { Common salt } \\
(\mathrm{g} / \mathrm{kg})\end{array}$ & 0 & 10 & 10 \\
\hline Total & 0 & 1000 & 1000 \\
\hline
\end{tabular}

$D_{0,}$ Farmer's diets (FD) only without the
supplementation of concentrate; $D_{1}, F D+$ supplemented with high energy concentrate diet; $D_{2}$, $F D+$ supplemented with low energy concentrate diet. DCP, Dicalcium phosphate.

The buffalo bull calves of control group $\left(D_{0}\right)$ received farmer's diets (FD) (gazing 5-6 hours, feeding straw and so on) only, without the supplementation of concentrate diet. Another two groups $\left(D_{1}\right.$ and $\left.D_{2}\right)$ of the buffaloes were received supplemented concentrate diet with different energy levels. The crude protein content in supplemented diets for both the groups was same. Feeding group $D_{1}$ received FD with the supplementation of concentrate diet according to body weight having high energy (13.77 MJ per kg $D M)$ and feeding group $D_{2}$ received FD with supplementation of concentrate according to body weight with low energy (12.14 MJ per kg DM). The crude protein content in supplemented diets was @ $125 \mathrm{~g}$ per kg/ DM. The concentrate diets were formulated using crushed maize, wheat bran, rice polish, broken rice, DCP, urea and salt at different proportions to maintain the required levels of energy and protein and are shown in Table 2. However, the chemical compositions of feed ingredients used in the supplemented concentrate diet are shown in Table 3.

\section{Feeding}

All the buffalo bull calves were supplied feed on the basis of their live weight and were adjusted fortnightly with their live weight changes.
Roughage and supplementation of concentrate diet were fed separately twice daily dividing into two equal portions and supplied at $6.30 \mathrm{hr}$ and $18.30 \mathrm{hr}$. The concentrate portion of the diet was supplied first followed by roughage. Fresh drinking water was made available to the buffaloes at all the times.

\section{Quantification of daily feed intake}

The feed intake was determined by subtracting the amount of left over from the amount of feed given on the previous day. Refusal was collected every morning before feed supply. The feed refused by the buffaloes during the period of 24 hours was weighed and recorded.

\section{Measurement of live weight of animals}

The live weight of growing buffalo bull calves were measured with the help of measuring tape and calculated using the Shaeffer's formula:

Live weight $=\frac{L \times G^{2}}{660} \mathrm{Kg}$

$L$, distance between point of shoulder to pin bone in inches; $G$, Hearth girth in inches.

\section{Cost-benefit ratio}

The cost-benefit ratio is a relative measure, which is used to compare benefits per unit of cost. The cost-benefit ratio estimated as a ratio of gross returns (milk \& meat) and gross costs (feed, labour, vaccine, medicine).

The formula of calculating cost benefit ratio is show below:-

$$
\text { Cost benefit ratio }=\frac{\text { Gross benefit }}{\text { Gross cost }}
$$

\section{Statistical analysis}

The data were analyzed to compute ANOVA and the mean values with standard error of difference (SED) were recorded (Steel and Torrie, 1980). Least significant difference (LSD) was done to compare the treatment means for different parameters. Analysis was done with the help of computer package program SAS v.9.

\section{Results and Discussion}

\section{Dry matter intake}

The nutrient intake of growing buffalo bull calves is shown in Table 4. The total DMI was higher in $D_{1}$ and $D_{2}$ compared with control and differed significantly $(p<0.01)$. The total DMI was found 
highest (4.82) in $D_{1}$ and the lowest (3.16) was found in control. The result of the present study is in agreement with the result of Hassan et al., (2013) and Tomar et al., (2014), they found that the DMI was significantly increased by increasing energy level in the ration in buffalo calves.
The DMI $(\mathrm{kg} / 100 \mathrm{~kg}$ BWT/day) of different treatment groups differed significantly $(p<0.01)$ between the treatment and control where the highest (2.82) DMI was found in $D_{2}$ followed by control (2.78) and the lowest (2.64) was found in $D_{1}$. The DMI was expressed as metabolic body weight $\left(\mathrm{g} / \mathrm{kg} \mathrm{W}^{0.75 / \mathrm{d})}\right.$ showed similar trend in result of DMI $(\mathrm{kg} / 100 \mathrm{~kg} \mathrm{BWT/day})$.

Table 3: Chemical composition of supplemented concentrate diet

\begin{tabular}{|c|c|c|c|c|c|c|c|c|c|c|}
\hline \multirow{2}{*}{ Ingredients } & \multirow{2}{*}{$\begin{array}{c}\text { DM (g/ } \\
100 \mathrm{~g} \\
\text { sample }\end{array}$} & \multicolumn{8}{|c|}{ Chemical composition (g/100g DM) } & \multirow{2}{*}{$\begin{array}{c}\text { ME } \\
(M J / k g \\
D M)\end{array}$} \\
\hline & & OM & CP & $\mathbf{C F}$ & EE & NFE & Ash & ADF & NDF & \\
\hline Diet $\mathrm{D}_{1}$ & 90.12 & 94.32 & 12.50 & 10.31 & 9.81 & 65.39 & 5.68 & 5.14 & 20.15 & 13.77 \\
\hline Diet $D_{2}$ & 90.41 & 96.65 & 12.48 & 12.38 & 9.82 & 66.39 & 3.05 & 3.05 & 15.25 & 12.14 \\
\hline
\end{tabular}

$D M$, Dry matter; OM, Organic matter; $C P$, Crude protein; $C F$, Crude fiber; $E E$, Ether extract; NFE, Nitrogen free extract; ME, Metabolizable energy; MJ, Mega joule; ADF, Acid detergent fiber; NDF, Neutral detergent fiber. Suppl. diet $\mathrm{D}_{1}$, Supplemented concentrate diet-1, Suppl. Diet $\mathrm{D}_{2}$, Supplemented concentrate diet-2.

Table 4: Effect of concentrate supplement on nutrient intake, body weight changes and feed conversion efficiency of buffalo bull calves

\begin{tabular}{|c|c|c|c|c|c|c|}
\hline \multirow{2}{*}{ Parameters } & \multicolumn{3}{|c|}{ Treatments (Mean \pm SE) } & \multirow{2}{*}{$\begin{array}{c}\text { Overall } \\
\text { Mean } \pm \text { SE }\end{array}$} & \multirow[b]{2}{*}{$\begin{array}{l}\text { LSD } \\
\text { Value }\end{array}$} & \multirow[b]{2}{*}{$\begin{array}{l}\text { Sig. } \\
\text { level }\end{array}$} \\
\hline & $D_{0}$ (Control) & $\mathbf{D}_{1}$ & $\mathbf{D}_{\mathbf{2}}$ & & & \\
\hline Total DMI & $3.16^{c} \pm 0.062$ & $4.82^{\mathrm{a}} \pm 0.079$ & $4.54^{b} \pm 0.060$ & $4.175 \pm 0.513$ & 0.209 & $* *$ \\
\hline $\begin{array}{l}\text { DMI }(\mathrm{Kg} / 100 \mathrm{~kg} \\
\text { BWT/day) }\end{array}$ & $2.64^{\mathrm{c}} \pm .003$ & $2.82^{\mathrm{a}} \pm 0.000$ & $2.78^{b} \pm 0.003$ & $2.74 \pm 0.546$ & 0.014 & $* *$ \\
\hline DMI $(\mathrm{g} / \mathrm{kg} \mathrm{W} \cdot 75 / \mathrm{d})$ & $26.39^{c} \pm 0.016$ & $28.22^{\mathrm{ab}} \pm 0.015$ & $27.79^{b} \pm 0.015$ & $27.47 \pm 0.552$ & 0.044 & $* *$ \\
\hline Total CPI (g/d) & $19.65^{c} \pm 0.375$ & $43.41^{\mathrm{a}} \pm .716$ & $38.27^{b} \pm 0.336$ & $33.77 \pm 7.22$ & 1.56 & $* *$ \\
\hline $\begin{array}{l}\text { Total CPI }(\mathrm{g} / \mathrm{kg} \\
\left.\mathrm{W}^{.75} / \mathrm{d}\right)\end{array}$ & $2.08^{b} \pm 0.021$ & $2.86^{a} \pm 0.029$ & $2.83^{\mathrm{a}} \pm 0.010$ & $2.594 \pm 0.255$ & 0.062 & $* *$ \\
\hline Total MEI (MJ/d) & $0.160^{\complement} \pm 0.00$ & $0.250^{\mathrm{a}} \pm 0.00$ & $0.230^{\mathrm{b}} \pm 0.00$ & $0.213 \pm 0.027$ & 0.014 & $* *$ \\
\hline MEI $\left(\mathrm{MJ} / \mathrm{kg} \mathrm{W}^{\cdot 75} / \mathrm{d}\right)$ & $0.160^{\mathrm{C}} \pm 0.00$ & $0.250^{\mathrm{a}} \pm 0.00$ & $0.230^{\mathrm{b}} \pm 0.00$ & $0.213 \pm 0.027$ & 0.014 & $* *$ \\
\hline $\begin{array}{l}\text { Initial body weight } \\
(\mathrm{kg})\end{array}$ & $98.40 \pm 2.14$ & $101.20 \pm 2.08$ & $98.80 \pm 2.29$ & $99.47 \pm 0.874$ & 6.69 & NS \\
\hline $\begin{array}{l}\text { Final body weight } \\
(\mathrm{kg})\end{array}$ & $144.0^{\mathrm{b}} \pm 2.34$ & $254.6^{\mathrm{a}} \pm 2.48$ & $249.2^{\mathrm{a}} \pm 2.60$ & $215.9 \pm 36.00$ & 7.63 & $* *$ \\
\hline $\begin{array}{l}\text { Average daily gain } \\
(\mathrm{g} / \mathrm{d})\end{array}$ & $190.0^{c} \pm 2.12$ & $639.2^{\mathrm{a}} \pm 3.39$ & $626.7^{b} \pm 3.87$ & $485.3 \pm 147.69$ & 9.89 & $* *$ \\
\hline FCE & $11.25^{\mathrm{a}} \pm 0.231$ & $6.91^{b} \pm 0.094$ & $6.53^{b} \pm 0.076$ & $8.233 \pm 1.51$ & 0.463 & $* *$ \\
\hline
\end{tabular}

$D_{1}$, Supplemented diet-1 containing $125 \%$ energy of NRC (2001) and $12.5 \% C P ; D_{2}$, Supplemented diet-2 containing $115 \%$ energy of NRC (2001) and 12.5\% CP; Control, Farmers feeding; SE, Standard error. NS, Non significant; *, Significant at 5\% level of probability; **, Significant at 1\% level of probability, SE, Standard error, LSD, Least significant difference. 


\section{Supplementation of concentrate diet to growing bull calf}

\section{Crude protein intake}

The total CP intake was higher in $D_{1}$ and $D_{2}$ compared with control and differed significantly $(p<0.01)$ between the treatment and control where highest (481.8) CP intake was found in $D_{1}$ and the lowest (236.2) was found in control. The CP intake ( $\mathrm{g} / 100 \mathrm{~kg} \mathrm{BW}$ ) was significantly higher in $20 \%$ higher energy fed group (286.39) compared with both control (259.27) and $10 \%$ higher energy fed group (267.15) of 7- 12 moth old male Murrah buffalo calves reported by Tomar et al., (2014), agreed with the present findings. The present findings closely associated with the findings of Shahzad et al., (2011), who found that the buffalo calves of 12-15 month-old perform adequately well when fed on diets containing $12.2 \% \mathrm{CP}$ and $2.10 \mathrm{Mcal} \mathrm{ME} / \mathrm{Kg}$ feed.

\section{Metabolizable energy intake}

The total MEI was higher in $D_{1}$ and $D_{2}$ compared with control and differed significantly $(p<0.01)$ between the treatment and control where highest total MEI was found in $D_{1}$ followed by $D_{2}$ and the lowest was found in control. The present findings closely associated with the findings of Shahzad et al., (2011), who found that the buffalo calves of 12-15 month-old perform adequately well when fed on diets containing $12.2 \% \mathrm{CP}$ and $2.10 \mathrm{Mcal}$ $\mathrm{ME} / \mathrm{Kg}$ feed. However, the metabolizable energy intake was expressed as metabolic energy intake $\left(\mathrm{MJ} / \mathrm{kg} \mathrm{W}^{0.75} / \mathrm{d}\right)$ showed similar trend in result of total MEI (MJ /day). Moreover, the nutrient intake of buffalo bull calves also influenced by the availability of feed, quality of feed (freshness of the feed, mould condition, spoilage, taste, moisture and temperature), feeding management, body size, rumen health, water quality and accessibility, heat stress, overall animal health and nutrient supply.

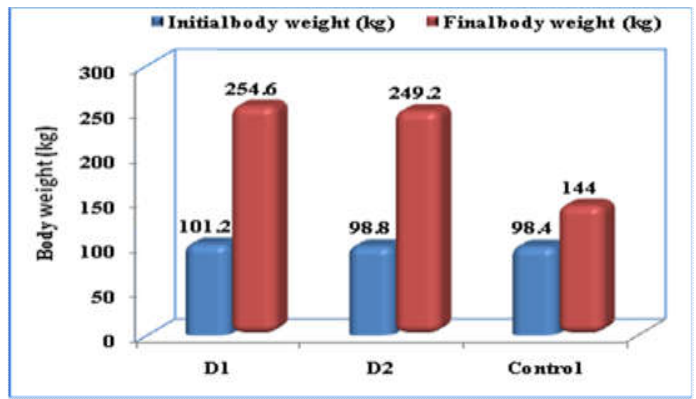

Figure 1: Initial and final body weight $(\mathrm{kg})$ of buffalo bull calves supplemented with concentrate diets in Subornochar Upozila

\section{Body weight change}

The body weight change and average daily gain of growing buffalo bull calves is shown in Table 4 and Figure 1 and 2 . The average initial body weight was higher in $D_{1}$ and $D_{2}$ compared with control and did not differ significantly $(p>0.05)$ within the treatment and control where the highest $(101.20 \mathrm{~kg})$ average initial body weight was found in $D_{1}$ and the lowest $(98.40 \mathrm{~kg}$ ) was found in control.

The final body weight of buffalo bull calves was higher in $D_{1}$ and $D_{2}$ compared with control and differed significantly $(p<0.01)$ but no significant differences $(p>0.05)$ were found within the treatment group of $D_{1}$ and $D_{2}$, where $D_{1}$ tended to be higher than $D_{2}$. The highest $(254.6 \mathrm{~kg})$ body weight was found in $D_{1}$ and the lowest $(144.0 \mathrm{~kg}$ ) was found in control. The average final body weight was increased by $153.40 \mathrm{~kg}(151.58 \%)$, $150.40 \mathrm{~kg}(152.22 \%)$ and $45.60 \mathrm{~kg}(46.34 \%)$ in $D_{1}, D_{2}$ and control, respectively, compared with initial body weight. On the other hand, the average final body weight of $D_{1}$ and $D_{2}$ was increased by $110.60 \mathrm{~kg}(76.80 \%)$ and $105.20 \mathrm{~kg}$ (73.05\%), respectively, compared with control. In this study the highest body weight was found in buffalo bull calves at $125 \%$ energy diet of NRC (2001) beef cattle steer requirements which disagreed with the result of Mahmoudazeh et al., (2007). They reported that significantly higher daily gain (503 to $951 \mathrm{~g} /$ day) was obtained when animals received medium energy diet that was similar to $100 \%$ beef cattle steer requirements. The body weight gain of buffalo bull calves in this study is in accordance with the findings of Kumar et al., (2011), Tomar et al., (2014) and Laxmi et al., (2014). They did not find any significant effect on body weight gain in male buffalo calves when fed rations having different energy levels.

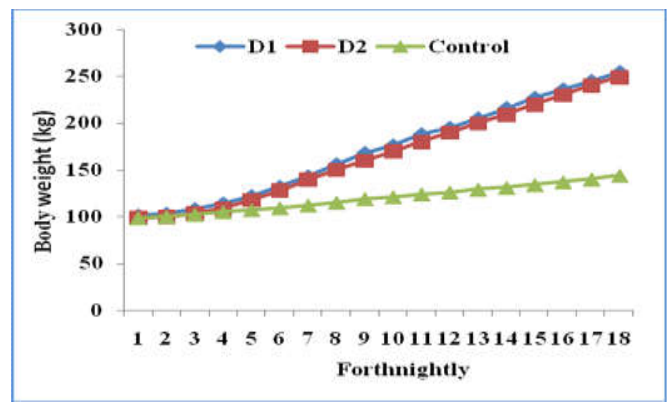

Figure 2: Trend of fortnightly body weight change $(\mathrm{kg})$ of buffalo bull calves in Subornochar Upozila 
Siddiki et al. (2021) Bang. J. Anim. Sci. 50 (1): 50-56

Table 5: Cost benefit analysis of farming buffalo bull calves according to treatments

\begin{tabular}{|c|c|c|c|c|}
\hline \multirow{2}{*}{ Parameter } & \multicolumn{3}{|c|}{ Treatments (Mean \pm SE) } & \multirow{2}{*}{$\begin{array}{l}\text { Level } \\
\text { of sig. }\end{array}$} \\
\hline & $\mathrm{D}_{0}$ (Control) & $\mathbf{D}_{1}$ & $\mathbf{D}_{\mathbf{2}}$ & \\
\hline Total cost (Tk/buffalo/day) & $31.40^{\mathrm{a}} \pm 3.01$ & $32.51^{b} \pm 2.93$ & $32.49^{b} \pm 2.69$ & $*$ \\
\hline Total income (Tk/buffalo/day) & $61.86^{a} \pm 4.24$ & $117.25^{b} \pm 5.62$ & $114.12^{b} \pm 4.43$ & $* *$ \\
\hline Total profit (Tk/buffalo/day) & $30.46^{\mathrm{a}} \pm 0.19$ & $84.74^{b} \pm 1.96$ & $81.72^{\mathrm{b}} \pm 1.04$ & $* *$ \\
\hline Cost- benefit ratio & $1: 1.97$ & $1: 3.60$ & $1: 3.51$ & \\
\hline
\end{tabular}

**, Significance at $1 \%$ level of probability; *, Significance at $5 \%$ level of probability; NS, Non-Significant; $D_{1}$, Supplemented diet -1 containing $125 \%$ energy of $N R C$ (2001) and $12.5 \% C P, D_{2}$, Supplemented diet -2 containing $115 \%$ energy of NRC (2001) and $12.5 \%$ CP; $\mathrm{D}_{0}$, Control, Farmers feeding; SE, Standard error.

\section{Average daily gain}

The ADG of buffalo bull calves was higher in $D_{1}$ and $D_{2}$ compared with control and differed significantly $(p<0.01)$ within the treatment and control where $D_{1}$ tended to be higher than $D_{2}$. The highest $(639.2 \mathrm{~g})$ ADG was found in $\mathrm{D}_{1}$ and the lowest $(190.0 \mathrm{~g})$ was found in control.

\section{Feed conversion efficiency}

Feed conversion efficiency of buffalo bull calves is presented in table 4 . The mean average FCE of different treatment groups differed significantly $(p<0.01)$ between the treatment and control but no significant differences $(p>0.05)$ were found within the treatment group of $D_{1}$ and $D_{2}$ where the highest (6.46) FCE was found in $D_{1}$ followed by $D_{2}$ (6.64) and the lowest (12.17) was found in control. The FCR ranged 5.2 to 5.8 when the animals received standard energy diet reported by Yunus et al., (2004) and Homayoun and Fazaeli, (2009), did not agree with the present findings. The feed conversion ratio for different energy and protein diets ranged from 6.9 to 7.6, reported by Mahmoudzadeh et al., (2007) in male buffalo calves, the result is in accordance with the present findings.

\section{Cost benefit analysis}

The cost benefit analysis of buffalo bull calves of Subornochar Upozila is presented in table 5. The cost benefit analysis of buffalo bull calves of different treatment groups differed significantly $(p<0.01)$ between the treatment and control but no significant differences $(p>0.05)$ were found within the treatment group of $D_{1}$ and $D_{2}$ where highest $(1: 3.60)$ cost benefit ratio was found in $D_{1}$ followed by $D_{2}(1: 3.51)$ and the lowest $(1: 1.97)$ was found in control.

\section{Conclusion}

Buffalo rearing is a profitable practice in the selected areas and improved the socio-economic status and livelihood of buffalo farmers; although the management practices need to be improved with scientific approaches.

\section{Acknowledgement}

The authors gratefully acknowledge the help and support in the form of timely fund availability and other infrastructural facilities provided by the Krishi Gobesona Foundation (KGF), Dhaka in carrying out this research work.

\section{Conflict of interest}

The authors declare that there is no conflict of interest that could be perceived as prejudicing the impartiality of the research reported.

\section{References}

Anonymous (2007). National Livestock Development Policy-2007, Livestock Section-2, Government of the People's Republic of Bangladesh, Ministry of Fisheries and Livestock. Pp: 1-35.

Banglapedia (2021). Livestock sub sectors. National Encyclopedia of Bangladesh.

Basar MJ, MA Khan, M Nisa, M Riaz, NA Tuqeer and MN Saeed (2003b). Nili-Ravi buffalo II. Energy and protein requirements of 9-12 months old calves. International Journal of Agriculture and Biology 5(3): 382-383.

BBS (2011). Bangladesh Bureau of Statistics Statistical Year Book of Bangladesh Bureau of Statistics, Statistics Division, Ministry of Planning, Government of the Peoples of Bangladesh, Dhaka, Bangladesh. Pp:195.

Begum IA, MJ Alam, J Buysse, A Frija and G Van Huylenbroeck (2011). A comparative efficiency analysis of poultry farming systems in Bangladesh; A Data Envelopment Analysis approach. Applied Economics 44: 37373747. 


\section{Supplementation of concentrate diet to growing bull calf}

DLS (2020). Department of Livestock Services, Annual Report on Livestock economy, Division of Livestock Statistics, Ministry of Fisheries and Livestock, Farmgate, Dhaka, Bangladesh.

FAO (2008). Food and Agriculture Organization of the United Nations, statistical databases. FAO, Rome, Italy.

FAOSTAT (2014). The statistical division of the Food and Agriculture Organizam. http:// fao.org/ag/againfo/themes/en/meat/backgroun d.html. Accessed on December, 2015.

Heinz Gunther (2001). Water buffaloes as meat animals. Proceeding, Regional Workshop in Water Buffalo Development, Surin, Thailand pp 10-17.

Helal FIS, KM Abdel Rahman, BM Ahmed and SS Omar (2011). Effect of feeding different levels of concentrates on buffalo calves performance, digestibility and carcass traits. American Eurasian Journal of Agriclture and Environment Scieence 10(2): 186-192.

Homayoun M and H Fazaeli (2009). Growth response of yearling buffalo male calves to different dietary energy levels. Turky Journal of Veterinary and Animal Science 33(6): 447-457.

Kandeepan G, ASR Anjaneyulu, N Kondaiah, SK Mendiratta and V Lakshmanan (2009). Effect of age and gender on the processing characteristics of buffalo meat. Meat Science 83: $10-14$.

Kumar SD, JR Prasad and ER Rao (2011). Effect of dietary nclusion of yeast culture (saccharomyces cerevisiae) on growth performance of graded murrah buffalo bull calves, Buffalo Bulletin 30(1): 63-66.

Laxmi A, N Gorakh and P Shiv (2014). Efficacy of blood plasma igfi as a marker and implications of fermented yeast culture in improvement of growth performance of low body weight murrah buffalo calves, Asia Pacific Journal of Research I(XIV): 42-52.

Mahmoudzadeh $\mathrm{H}$, H Fazaeli, I Kordnejad and HR Mirzaei (2007). Response of male buffalo calves to different levels of energy and protein in finishing diets. Pakistan Journal of Biological Sciences 10:1398-1405.

NARS (2010). National Agricultural Research System, Agricultural Research Priority; Vision 2030 and beyond. Bangladesh Agricultural Research Council, Farmgate, Dhaka, Bangladesh.

Neath KE, AN Del Barrio, RM Lapitan, JRV Herrera, LC Cruz, T Fujihara, S Muroya, K Chikuni, M Hirabayashi and Y Kanai (2007). Difference in tenderness and $\mathrm{p}^{\mathrm{H}}$ decline between water buffalo meat and beef during postmortem aging. Meat Science 75: 499-505.

NRC (2001). National Research Council; Nutrient Requirements of Beef Cattle $7^{\text {th }}$ edition Washington, DC: National academy press 381.

Shahzad MA, AN Tauqir, A Fayyaz, U Mahr, N Sarwar and MA Tipu (2011). Effects of feeding different dietary protein and energy levels on the performance of 12-15-month-old buffalo calves. Tropical Animal Health Production 43: 685-694.

Steel RGR and JH Torrie (1980). Principles and Procedures of Statistic, $2^{\text {nd }}$ edition. Mc GrawHill International Book Corporation, New Delhi, India.

Tipu MA, RH Mirza, F Ahmad, NA Tauqir and M Aziz (2009). Effect of varying levels of dietary protein on the performance of growing Nili-Ravi buffalo male calves. Buffalo Research Institute, Pattoki, District Kasur, Pakistan.

Tomar SK, LN Patil, P Singh and SS Kundu (2014). Effect of feeding various energy levels on nutrient utilization and growth in male buffalo calves. The Journal of Animal and Plant Sciences 24 (1): 33-35.

Yunus AW, AG Khan, Z Alam, JI Sultan and M Riaz (2004). Effects of substituting cottonseed meal with sunflower meal in rations for growing buffalo calves. Asian Australian Journal of Animal Science 17: 659-662. 